\title{
Critical Race Media Literacy for These Urgent Times ${ }^{1}$
}

\author{
Tara J. Yosso \\ University of California, Riverside \\ U.S.A.
}

ABSTRACT: Tara J. Yosso reflects on the genealogies of her research on visual microaggressions and the future directions for critical race media literacy scholarship. She identifies a need for sustained attention in three areas: (1) the intentionality of racial imagery, and recognition of media as pedagogy; (2) the role of history and the continuities of racial scripts applied against different groups; and (3) contestations of majoritarian narratives across generations.

KEYWORDS: critical race media literacy, visual microaggressions, Hollywood urban school genre, Latina/o students

References

Author Contact

This essay is in part a reflection of my 2002 publication, "Critical Race Media Literacy: Challenging Deficit Discourse about Chicanas/os," in the Journal of Popular Film and Television. The article developed from my dissertation, and thinking about this research almost two decades later, memories flood back. I am brought back to the anger and sense of urgency I felt as a first generation college student and emerging scholar asking critical questions about race, media, and education. My research was driven by what I saw as an underexamined, but obvious, connection between California's multi-year legislative assault on Communities of Color and the release of Hollywood films such as Dangerous Minds (1995), The Substitute (1996), High School High (1996), and 187 (1995). These films portrayed Latina/o and Black students as "suspects" who burden and menace mainstream society. I remember politicians and filmmakers sending similar messages, insinuating that moral depravity and cultural poverty emanate from Mexican and Central American communities in particular. I recall the duplicitous language, such as Save our State (Prop 187), English for the Children (Prop 227), Civil Rights Initiative (Prop 209), and Juvenile Justice (Prop 21) attempting to disguise the legislations' dubious intent. I studied the condescending ways studios packaged and marketed the "urban high school genre" with rap artists on movie soundtracks, music video montages inserted into dramatic scenes, and actors costumed in hip-hop fashion (Yosso, 2000).

\footnotetext{
${ }^{1}$ Part of this title is inspired by Culture Clash's 1992 play written in the wake of the Rodney King verdict and the Los Angeles uprisings S.O.S.-Comedy for These Urgent Times (see California State University Northridge Oviatt Library Culture Clash Archive).
} 
These images reminded me of the cholas/cholos of the Chicana/o gang film genre from the late 1970s, 1980s, and 1990s (e.g., Walk Proud, 1979; Boulevard Nights, 1979; Colors, 1988; American Me, 1992, Blood in Blood Out, 1993; Mi Vida Loca, 1994). Extending the scope of my study further challenged me to recognize these characters' historical counterparts in the "greaser," bandido, and spitfire/harlot stereotypes of early cinema and through most of the $20^{\text {th }}$ century (e.g., Cortés, 1995; Noriega, 1992; Ramírez Berg, 1997, 2002; Romero, 2001).

Identifying the historical continuities of those one-dimensional portrayals led me to examine what purpose such images served across time. Building on some of the work scholars had done around repetitive metaphors in newspapers, racial imagery in print advertisements, and stereotypical depictions of Blacks on television and film (e.g., Hall, 1981; Santa Ana, 2002; Wilson \& Gutierrez, 1995) I began to map the patterns of representation in Hollywood's "urban school genre."

Starting with Blackboard Jungle (1955), I found a teacher heroically convincing Latina/o and Black youth to embrace the "American" (Anglo) cultural values they initially rejected. Likewise, through drama, comedy, action, and psychological thriller, these films entertain a historical imperative (Williams, 1985). Building on politically conservative historical contexts, they blame the victims of racialized inequalities and renege institutional responsibility for public schools and Youth of Color. This formula amplifies a distorted and incomplete view with a patronizing narrative characterizing Black and Latina/o high school students as delinquents dependent on the benevolence of a (usually) White teacher or administrator. The films I was studying in the 1990s followed this formula. When the protagonist was a male, the film depicted a teacher or principal using brute force to beat down the supposed juvenile delinquency problem (see Lipsitz, 1998). When the protagonist was a female, the same formula applied, but the teacher was portrayed as a moral authority, using a righteous dare-to-care philosophy to uplift otherwise "uneducable," "at-risk" Students of Color. This unoriginal narrative exploits a century of racial stereotypes to capitalize on the fears of a predominately White electorate. With unrelenting repetition, each film contributes to the myth that increasing populations of Latinas/os and Blacks in public schools lead to a rise in violence and crime, demonizing students and their communities for dramatic effect (e.g., Dorfman \& Schiraldi, 2001; Fernández \& Yosso, 1997; Yosso \& García, 2008, 2010).

While my dissertation was motivated in large part by my frustration with such distortions being promoted as "based on a true story," I felt compelled to move beyond critical content analysis and toward a deeper understanding of the "impact" of that content. In this regard, I turned to Carlos Cortés and his colleagues, who had been utilizing films as pedagogical tools in teaching history since the 1970s (e.g., Campbell, Cortés, \& Pinger, 1975). I studied their approach to analyzing films as curriculum in the classroom and naming films as part of the "societal curriculum" (Cortés, 1992, p. 92). I paid particular attention to Cortés' caution to researchers about the difficulty of even identifying Chicana and Chicano characters on film, let alone finding a way to assess the "impact" of those 
Hollywood portrayals. Motivated by his reminder that "media serve as pervasive, relentless, lifelong educators" (Cortés, 1992, p. 92), I took on the challenge.

In this effort, I drew heavily on the work of Chester M. Pierce, who had been writing about the interconnection between racism in the media and schools long before I began my own educational trajectory. Specifically, I built on his astute conceptualization of microaggressions as a major tool for structural racism, occurring subtly, incessantly and with a purpose of teaching White superiority (e.g., Pierce, 1969, 1974, 1988, 1995; Pierce et al., 1978). Pierce emphasized that the cumulative individual, group, and societal "impact" of racial microaggressions was devastating and difficult to measure (see also Carroll, 1998). Extending on Pierce, my definition aimed to account for the intercentricity of racism with other forms of subordination evident in the experiences of Chicana/o, Latina/o students, such as those in my original study (e.g., Solórzano, 1998; Solórzano \& Yosso, 2001). I added the terms visual and layered in an attempt to more precisely name some of the multifaceted elements of racially "offensive mechanisms" projected on film:

Microaggressions are subtle (verbal, non-verbal, visual) insults of People of Color, often done automatically or unconsciously. Microaggressions are layered insults, based on notions of race, gender, class, sexuality, culture, language, immigration status, phenotype, accent, and surname. Microaggressions are cumulative and cause unnecessary stress to People of Color while privileging Whites (Yosso, 2002, p. 60).

Fast forward to Spring 2016, when the Southern Poverty Law Center's (SPLC) report, The Trump Effect: The Impact of the Presidential Campaign on our Nation's Schools echoed the urgency driving critical race media literacy. The SPLC conducted a survey of 2,000 teachers who were subscribers to and users of their Teaching Tolerance website to learn about how they were pedagogically dealing with the 2016 U.S. presidential election (Costello, 2016). These educators indicated they felt profoundly troubled by the racial rhetoric of presidential candidate Donald J. Trump and the almost immediate impact on their students. Over two-thirds of the teachers reported their students held visceral "fears about what might happen to them or their families after the election," over half saw "an increase in uncivil political discourse," and over one-third "observed an increase in anti-Muslim or anti-immigrant sentiment" (Costello, 2016, p. 4). Teachers further reported serious concern that some students felt emboldened by Trump's racial rhetoric to engage in hate speech, public intimidation, and overt hostility toward peers perceived as immigrants, Muslims, Mexicans, and Blacks. I deeply understood the sense of urgency expressed by these educators in trying to deal with what the SPLC termed "The Trump Effect" in schools.

At this writing, as a professor at a Research I university and a mother of two school-age children, my sense of urgency remains and has taken on new dimensions. Confronting the sheer volume and velocity of visual microaggressions leaves me outraged and exhausted at once. I worry about becoming numb. Beyond a reflection about the genealogies of my research, with this essay I am also thinking about the future directions for critical race media literacy scholarship. I see a need for sustained attention in three areas: (a) the intentionality of racial 
imagery, and recognition of media as pedagogy; (b) the role of history and the continuities of racial scripts applied against different groups; and (c) contestations of majoritarian narratives across generations.

Pierce (1974) described daily interpersonal racial microaggressions as being done "in automatic, preconscious, or unconscious fashion" (p. 515), but I assert that visual microaggressions, such as those on film, carry a distinct element of intention, projected by commission and omission. ${ }^{2}$ Filmmakers may claim they are unaware that images, dialogue, or other elements of the production are degrading (i.e., White actors performing in brownface), but they cannot argue that the demeaning portrayals are unintentional. As I analyze media's visual microaggressions, I do so conscious that they are "a major vehicle of racism" (Pierce, 1974, p. 515), and they did not become part of any given film by chance. Once we "see" that the racialized imagery on film has been systematically constructed, then we again ask what purpose do these images serve, and specifically, what do these images aim to teach?

Pursuing these questions, I also see the need for more attention on the intentionality of omission. For instance, the urban school formula about Students of Color as a racial problem requiring the intervention of a White teacher is enacted by portraying stereotypes and distortions on screen while simultaneously omitting community histories shaping contemporary schooling conditions. Filmmakers can claim they are unaware of how ahistorical narratives diminish the humanity of People of Color, but cannot claim that these histories and contexts are omitted as a series of accidental production errors. We need to keep asking whose perspectives are portrayed and what purpose is served by repeatedly silencing or rendering invisible entire groups of people-even in films ostensibly telling their stories? Hollywood studios recognize and capitalize on the power of films to influence public perceptions and social policy. While they often claim artistic license in creating entertainment, filmmakers, just like other professionals, are aware of the impacts of their work.

Recognizing media as part of the "societal curriculum," my work has been not only to critically read films as racial texts, but to facilitate students' identification of patterns and changes in these visual racial narratives across time. George Lipsitz has offered critical insights about why history matters. He explains that commercial motion pictures "are historical in the sense of being cultural artifacts and social-history evidence about the times in which they were made. But films are historical in another way as well: they reposition us for the future by reshaping our memories of the past" (Lipsitz, 1990, p. 164). Patterns of erasure and invisibility in front of and behind the camera have tremendous impacts in shaping our collective memory (e.g., Navarette \& Kamasaki, 1994; Smith et al., 2019). We need to take these history matters into account.

\footnotetext{
2 In my dissertation and subsequent publications, I also discuss the intentionality of institutional microaggressions and of racial jokes as microaggressions (see Yosso, 2000; Yosso, Smith, Ceja, \& Solórzano, 2009).
} 
My mapping of the deficit frames used to justify the under-education of Latina/o and Black students across time is strengthened by taking up Natalia Molina's (2014) call to pay attention to enduring "racial scripts" that "highlight the ways the lives of racialized groups are linked across time and space" (pp. 6-7). Studying racial scripts employed to subjugate Native Americans in one era, and redeployed under different conditions to oppress African Americans, facilitates our view of connections between and among groups. Such an approach can further demonstrate continuities and contradictions in the efforts to maintain a racial hierarchy. For example, we can examine how Trump is resurrecting and weaponizing racial scripts with one-dimensional derogatory references to Mexicans as "bad hombres."

Casting a critical historical light on the explicitly anti-Mexican sentiments expressed by presidential candidate Trump, and since amplified by President Trump and his cabinet appointees, can expose those scripts as unoriginal and contested. Without such context, the entire world is subjected daily to wall-to-wall coverage of racial microaggressions, passed off as "breaking news." Such racist vitriol are attempts to dehumanize with an explicit purpose of justifying cruel policies for Latina/o communities.

While I argue that the future of critical race media literacy should be driven by a deeper examination of our past, I am reminded to look back at contestations of majoritarian narratives as well. As we excavate how dominant narratives and power structures link different racialized groups across time, we can also train our lens to recognize a shared legacy of resistance to oppression. For example, in my dissertation, I highlighted the protest of 100 Santa Monica High School (SAMO) students who marched onto Activision headquarters demanding an apology and a recall of the Toy Story 2 video game. They expressed outrage that at level 11, the enemy that Buzz Lightyear must annihilate was undeniably designed to portray a Mexican bandido - a man with a sombrero, making a menacing face with a large black mustache, bandolier, and a rifle. He explodes into gold coins after being blasted. At no other level of the game were any human representations the targets of Buzz Lightyear's destruction, and this bandit was not a character in the Toy Story 2 film. Joined by their teachers, community organizations, and local and state officials, the students denounced the racist, insidious message packaged as a game for children. María Vivanco, a 15-year-old SAMO student, told the reporter from La Opinion, "Nosotros estámos cansados de recibir ese tipo de ofensas...Además, dice que a los niños que maten al Mexicano o al Latino" (We're tired of these insults...And furthermore, it tells children to kill Mexicans or Latinos.") (Vega, 1999, p. 1B). In her remarks, I heard echoes of Paulo Freire's $(1970,1973)$ observations about how the power of education as a tool of oppression exists alongside its power as a tool of emancipation. María and her peers exposed the tools of the oppressor, and in their public reclamation, they demonstrated the possibilities of education as a site of empowerment.

I have also evoked Freire's legacy in writing about the HBO film Walkout (2006), which disrupted the urban school genre with a story about Chicana/o students organizing what became known as the 1968 East Los Angeles Blowouts 
(Yosso \& García, 2008, 2010). Released on HBO rather than in theaters, Walkout stood out in the urban school genre because it did not malign Chicana/o students or their parents with a one-dimensional, ahistorical portrayal. Walkout acknowledged the importance of Lincoln High School teacher Mr. Sal Castro, without reverting to the teacher-as-hero formula. The film showed how teaching history in all its complexities led to empowerment and community transformation. We should continue to study and teach about films that push against the dominant narrative. When we do, we facilitate students seeing themselves not just as subjects of history, or of films, but as participants_and potentially as filmmakers. We also need more films like Robert Townsend's satire about aspiring African American actors being relegated to doing the Hollywood Shuffle (1987).

Even as I continue doing the work of preparing the next generation of scholars and practitioners' to engage critical race media literacy, I am convinced there is much more to do to make these analytical tools accessible for wider audiences (e.g., Alemán, 2014). This need has become amplified in our contemporary moment. Thousands of protestors took to the streets in summer 2018 when the news media reported on the U.S. government's purposeful orphaning of mainly Central American asylum-seeking children. The pictures and video clips smuggled out of the detention centers offered a heart wrenching glimpse of men, women, and children in cages, and the audio clips of children crying and negotiating for their freedom were haunting. News outlets scrambled to piece together narratives of these families and the countries they came from, but rarely mentioned the conditions of violence, climate change, and dire poverty driving these predominantly indigenous communities north. Even within more nuanced news discussions, there was almost no attempt at offering a broader historical context that included the political and economic relationship between the U.S. and these countries (e.g., Galeano, 1997; Sassen, 1992). Collective memory is a powerful tool often underestimated when thinking about media analysis. I was reminded of this when news stories began surfacing about many protestors recognizing the dehumanizing treatment of child and family detainees as connected to the internment of Japanese Americans during WWII, to the separation of Native American children from their families in boarding schools, and to the cruelties inflicted on the Jews in concentration camps. They called on an intergenerational history of trauma and mobilized against the flagrant violations of human rights by the Trump administration. As they contested the majoritarian narrative, they constructed a racial counterscript. I take heart in these reclamations of our shared humanity, and I offer this essay with renewed appreciation for Freire's assertion that "critical reflection is also action" (p. 109).

\section{References}

Alemán, S. M. (2014). "Reimagining journalism education through a pedagogy of counter-news-story." Review of Education, Pedagogy, and Cultural Studies, (36), 2, 109-126. 
Campbell, L. G., Cortés, C., \& Pinger, R. (1975, October). Latin America: A FilmicApproach. (Film Series No. 1). Latin American Studies Program. Riverside, CA: University of California.

Carroll, G. (1998). Environmental stress and African Americans: The other side of the moon. Praeger.

Cortés, C. E. (1992). "Who is Maria? Who is Juan? Dilemmas of analyzing the Chicano image in U.S. feature films." In C. Noriega. (Ed.), Chicanos and film: Representation and resistance (pp. 74-93). University of Minnesota Press.

Cortés, C. E. (1995). "Knowledge construction and popular culture: The media as multicultural educator." In, J. A. Banks \& C. A. Banks (Eds.), Handbook of research on multicultural education (pp. 169-183). Macmillan.

Costello, M.B. (2016). The Trump Effect: The impact of the presidential campaign on our nation's schools. A report on teaching the 2016 election. Southern Poverty Law Center. Retrieved from https://www.splcenter.org/20160 413/trump-effect-impact-presidential-campaign-our-nations-schools

Dorfman, L., \& V. Schiraldi. (2001). "Off balance: Youth, race \& crime in the news." Building Blocks for Youth Initiative. Justice Policy Institute. Retrieved from http://www.justicepolicy.org/research/2060

Fernández, J., \& Yosso, T.J. (Monday August 18). “'187' demonizes Latino, African American students." Los Angeles Times, p. F3.

Freire, P. (1970). Pedagogy of the oppressed. Continuum Publishing Company.

Freire, P. (1973). Education for a critical consciousness. The Seabury Press.

Galeano, E.H. (1997). The open veins of Latin America: Five centuries of the pillage of a continent. $25^{\text {th }}$ anniversary edition. Monthly Review Press.

Hall, S. (1981). "The whites of their eyes: Racist ideologies in media." In G. Bridges \& R. Brunt (Eds.), Silver linings: Some strategies for the eighties (pp. 2852). Lawrence \& Wishart.

Lipsitz, G. (1990). Time passages: Collective memory and American popular culture. University of Minnesota Press.

Lipsitz, G. (1998). The possessive investment in whiteness: How White people profit from identity politics. Philadelphia: Temple University Press.

Navarrete, L., \& Kamasaki, C. (1994). Out of the picture, Hispanics in the media: State of Hispanic America, 1994. University of Texas Policy Analysis Center, Office of Research Advocacy and Legislation. National Council of La Raza.

Noriega, C.A. (Ed.) (1992). Chicanos and film: Representation and resistance. University of Minnesota Press.

Molina, N. (2014) How race is made in America: Immigration, citizenship, and the historical power of racial scripts. University of California Press. 
Pierce, C.M. (1974). Psychiatric problems of the Black minority. in, S. Arieti (Ed.), American handbook of psychiatry (pp. 512-523). Basic Books.

Pierce, C. M. (1975). Poverty and racism as they affect children. In I.N. Berlin. (Ed.), Advocacy for child mental health (pp. 92-109). Brunner/Mazel Publishers.

Pierce, C. M. (1980). Social trace contaminants: Subtle indicator of racism in tv. In S. B. Withey \& R. P. Abeles (Eds.), Television and social behavior: Beyond violence and children. A report of the committee on television and social behavior social science research council (pp. 249-257). Lawrence Erlbaum Associates.

Ramírez Berg, C. (1997). "Stereotyping in films in general and of the Hispanic in particular." In C. Rodríguez (Ed.), Latin looks: Images of Latinas and Latinos in the U.S. media (pp. 104-120). Westview Press.

Ramírez Berg, C. (2002). Latino images in film: Stereotypes, subversion, and resistance. University of Texas Press.

Romero, M. (2001). State violence and the social and legal construction of Latino criminality: From el bandido to gang member. Denver University Law Review, 78 (4), 1081-1118.

Sassen, S. (1992, July). Why immigration? Report on the Americas, 26 (1) 14-19.

Smith, S.L., Choueiti, M., Case, A., Pieper, K., Clark, H., Hernandez, K., Martinez, J., Lopez, B., \& Mota. M. (2019). Latinos in film: Erasure on screen \& behind the camera across 1,200 popular movies. Annenberg Inclusion Initiative: University of Southern California.

Santa Ana, O. (2002). Brown tide rising: Metaphors of Latinos in the contemporary American public discourse. University of Texas Press.

Solórzano, D.G. (1997). Images and words that wound: Critical race theory, racial stereotyping, and teacher education. Teacher Education Quarterly, 24(3), 5-19.

Solórzano, D.G., \& T.J. Yosso. (2001). Critical race and LatCrit theory and method: Counterstorytelling Chicana and Chicano graduate school experiences. International Journal of Qualitative Studies in Education, 14(4), 371-395.

Vega, M. (1999, December 10). Protestan por personaje latino en juego: La compania walt disney anuncia que eliminara un segmento del videojuego 'toy story 2.' (Protest over Latino character in game: Walt disney company announces that it will remove a segment of video game 'toy story 2') La Opinion, $1 \mathrm{~B}$.

Williams, L. (1985). "Type and stereotype: Chicano images in film." In G.D. Keller (Ed.), Chicano cinema: Research, reviews, and resources (pp. 59-63). Bilingual Press/Editorial Bilingüe.

Wilson, C.C., II, \& Gutierrez, F. (1995). Race, multiculturalism, and the media: From mass to class communication $\left(2^{\text {nd }}\right.$ ed.). Sage. 
Yosso, T.J. (2000). A critical race and LatCrit approach to media literacy: Chicana/o resistance to visual microaggressions. Unpublished doctoral dissertation, University of California, Los Angeles.

Yosso, T.J. (2002). Critical race media literacy: Challenging deficit discourse about Chicanas/os. Journal of Popular Film and Television, 30(1), 52-62.

Yosso, T.J., Smith, W.A., Ceja, M., \& Solórzano, D.G.. (2009, Winter). Critical race theory, racial microaggressions, and campus racial climate for Latina/o undergraduates. Harvard Educational Review, 79(4), 659-690.

Yosso, T.J., \& García, D.G. (2008). "'Cause it's not just me': Walkout's history lessons challenge Hollywood's urban high school formula. Radical History Review, 102, 171-184.

Yosso, T.J., \& García, D.G. (2010). "From Ms. J. to Ms. G.: Analyzing racial microaggressions in Hollywood's urban school genre." In B. Frymer, T. Kashani, A.J. Nocella II, \& R. Van Heertum (Eds.), Hollywood's exploited: Public pedagogy, corporate movies, and cultural crisis (pp. 85-103). Palgrave Macmillan.

\section{Author Contact}

Tara J.Yosso, t.yosso@ucr.edu University of California at Riverside, Graduate School of Education 900 University Avenue, Sproul Hall, Riverside, CA 92521 